\section{REFERENCES AND NOTES}

1. Baehner, L. R., Johnston, R. B., and Nathan, D. G.: Comparative study of the metabolic and bactericidal characteristics of severely glucose-6-phosphate dehydrogenase deficient polymorphonuclear leukocytes and leukocytes from children with chronic granulomatous disease. J. Reticuloendothel. Soc., 12: 150 (1972).

2. Baehner, L. R., and Nathan, D. G.: Quantitative nitroblue tetrazolium test in chronic granulomatous disease. New Engl. J. Med., 278: 971 (1968)

3. Bellanti, J. A., Cantz, B. E., and Schlegel, R. J.: Accelerated decay of glucose-6-phosphate dehydrogenase activity in chronic granulomatous disease. Pediat. Res., 4: 405 (1970).

4. Bonsignore, A., Fornaini, G., Leoncini, G., Fantoni, A., and Segni, P.: Characterization of leukocyte glucose-6-phosphate dehydrogenase in Sardinian mutants. J. Clin. Invest., 45: 1865 (1966).

5. Cooper, M. R., DeChatelet, L. R., McCall, C. E., LaVia, M. F., Spurr, C. L. and Baehner, L. R.: Complete deficiency of leukocyte glucose-6-phosphate dehydrogenase with defective bactericidal activity. J. Clin. Invest., 51: 769 (1972).

6. Erickson, R. P., Stites, D. P., Fudenberg, H. H., and Epstein, C. J.: Altered levels of glucose-6-phosphate dehydrogenase stabilizing factors in X-linked chronic granulomatous disease. J. Lab. Clin. Med., 80: 645 (1972).

7. Gray, G, R, Klebanoff, S, J., Stamatoyannopoulos, G., Austin, T., Naiman, S. C., Yoshida, A., Kliman, M. R., and Robinson, G. C. F.: Neutrophil dysfunction, chronic granulomatous disease and nonspherocytic haemolytic anaemia caused by complete deficiency of glucose-6-phosphate dehydrogenase. Lancet, ii: 530 (1973).

8. Justice, P., Shih, L., Gordon, J., Grossman, A., and Hsia, D. Y.: Characterization of leukocyte glucose-6-phosphate dehydrogenase in normal and mutant human subject. J. Lab. Clin. Med., 68: 552 (1966).

9. Lowry, O. H., Rosebrough, N. J., Farr, A. L., and Randall, R. J.: Protein measurement with the Folin phenol reagent. J. Biol. Chem., 193: 265 (1951).

10. Marks, P. A., and Gross, R. T.: Erythrocyte glucose-6-phosphate dehydrogenase deficiency: Evidence of difference between Negroes and Caucasians with respect to this genetically determined trait. J. Clin. Invest., 38: 2253 (1959).

11. Quie, P. G., White, J. G., Holmes, B., and Good, R. A.: In vitro bactericidal capacity of human polymorphonuclear leukocytes: Diminished activity in chronic granulomatous disease of childhood. J. Clin Invest., 46: 668 (1967).

12. Ramot, B., Bauminger, S., Brok, D., Gafni, D., and Scwartz, S.: Characterization of glucose-6-phosphate dehydrogenase in Jewish mutants. J. Lab. Clin. Med., 64: 895 (1964).

13. Ramot, B., Fisher, S., Szeinberg, A., Adams, A., Sheba, C., and Gafni, D.: A study of subjects with erythrocyte glucose-6-dehydrogenase deficiency. II. Investigation of leukocyte enzyme. J. Clin. Invest., 38: 2234 (1959).

14. Rattazzi, M. C., Bernini, L. F. Fiorelli, G., and Mannucci, P. M., Electrophoresis of glucose-6-phosphate dehydrogenase: A new technique. Nature, 213: 79 (1967)

15. Rodey, G. E., Jacob H. S., Holmes, B., McArthur, J. R., and Good, R. A.: leukocyte G6PD levels and bactericidal activity, Lancet, $i \cdot 335$ (1970).

16. Russo, G.: Il favismo in Sicilia. Riv. Pediat. Sic., 22: 296 (1967)

17. Russo, G., Schilirò, G., and Gallone, G.: Caratterizzazione della carenza di G6FD in soggetti Siciliani. Riv. Pediat., 29: 296 (1969).

18. Schilirò, The G6PD deficiency in Sicili. (In press.)

19. Schilirò, G., Gallone, G., and Distefano, G.: Caratterizzazione del difetto di G6FD nella popolazione siciliana. Nota 1: Livelli di attività enzimatica leucocitaria. Riv. Pediat. Sic., 23: 533 (1968).

20. Sococcia, P., Holmes, B., and Good, R. A.: Unpublished observations cited by B. Holmes. In: R. C. Williams and H. H. Fudenberg: Phagocytic Mechanisms in Health and Disease, p. 57 (Georg Thieme, Stuttgart, 1972).

21. Spire, Z., Binor, Z., and Bogair, N.: G6PD and childhood infection. Lancet, ii. 661 (1971).

22. World Health Organization: Series de rapport techniques 1967 no. 366.

23. Yoshida, A.: Hemolytic anemia and G6PD deficiency. Science, 179: 532 (1973).

24. Zinkham, W. H. Lenhard, R. E., Jr., and Childs, B. A.: A deficiency of glucose-6-phosphate dehydrogenase activity in erythrocytes from patients with favism. Bull. Johns Hopkins Hosp., 102: 169 (1958).

25. Requests for reprints should be addressed to: G. Schilirò, M.D., Department of Pediatrics, V. le A. Doria, 95100 Catania (Italy).

26. Accepted for publication March 3, 1976
Acini

calcium

cystic fibrosis lobular ducts pancreas morphology islets

\title{
The Pancreas in Cystic Fibrosis: Chemical Composition and Comparative Morphology
}

\author{
L. E. KOPITO AND H. SHWACHMAN ${ }^{123}$ \\ Department of Clinical Nutrition, The Ina Sue Perlmutter Cystic Fibrosis Center, The Children's Hospital \\ Medical Center, and the Department of Pediatrics, Harvard Medical School, \\ Boston, Massachusetts, USA \\ G. F. VAWTER AND J. EDLOW \\ Department of Pathology, The Children's Hospital Medical Center and Harvard Medical School, \\ Boston, Massachusetts, USA
}

Extract

Sections of pancreas from 16 individuals who died with cystic fibrosis (CF) were classified by morphometric criteria into four categories in increasing order of pancreatic involvement. The concentration of acini, islets, main ducts, lobular ducts, connective tissue, and fat was compared with control levels. The results show that in the least involved pancreases, from neonates who died under 5 months of age, acini were reduced to $33 \%$ of control levels and the following were increased: islets, to $410 \%$; lobular ducts, to $250 \%$; and main ducts, to $1700 \%$ of controls.

With increasing severity of the pancreatic disease the acini were further reduced to $5 \%$ and lobular ducts to $37 \%$ of control levels, respectively. Main ducts increased by 19 -fold, and fatty infiltration accounted for more than $25 \%$ of the fresh weight of the pancreas in 9 of the 16 specimens.

Comparative biochemical studies of 35 fibrocystic pancreases were quantitatively related to the severity of the pancreatic involvement as follows. Water and volatile matter, normally accounting for $80_{ \pm} \%$ of the weight of the fresh pancreas, was reduced to less than $30 \%$ in the most affected organs. The concentration of zinc diminished from near normal mean levels of $193 \mu \mathrm{g}$ $\mathrm{Zn} / \mathrm{g}$ dry pancreas to $10 \%$ of this amount in the severely involved pancreas. 
Elevated concentrations of calcium, amounting to over 10 times control level, were found in obstructed ductal structures. Calcium was depleted from pancreatic sections adjacent to the obstructions. The following biochemical indicators were significantly different in their mean levels in the $\mathbf{3 5}$ fibrocystic pancreases when compared with the 17 controls: ( $P \leq \mathbf{0 . 0 0 1})$ fat, water, zinc, calcium, copper, magnesium, potassium, and sodium $(P \leq \mathbf{0 . 0 1})$.

\section{Speculation}

Morphometric and biochemical studies of the pancreas in cystic fibrosis are interpreted to favor an early and perhaps primary role of ductal and ductular abnormality in the pathogenesis of the pancreatic lesion. The principal basis for this suggestion lies in the demonstration of early massive enlargement of the ductular system and the consequent accumulation of viscous calcium-rich inspissated material responsible for the formation of functional ductal obstructions. Alterations in calcium concentration and binding in the pancreas and in pancreatic juice are believed to be responsible for changes in membrane permeability and the transport of water and electrolytes. The pancreatic disease process begins in utero and the digeneration of the pancreas progresses through life in nearly all patients with cystic fibrosis.

Cystic fibrosis accounts for nearly all young patients with pancreatic insufficiency (17). There is no known single defect to relate the various organ involvements in CF; each system presents with different degrees of affliction and with no correlation with the general severity of the disease. The onset of symptoms may vary considerably. In about $15 \%$ of our patients with CF the disease is evident at birth as a consequence of meconium ileus (7). In some patients (15-20\%) no pancreatic enzyme deficiency may be detected even as late as 10 years of age (18). In these patients the pancreatic lesion may be minimal; however, progression to the end stage of fatty replacement and extensive fibrosis occurs in most patients (1).

Alterations in calcium concentration and activity have been previously associated with biochemical and biophysical changes in various exocrine secretions from patients with $\mathrm{CF}(3,5,6,14$, 16).

Forstner et al. (8), in a recent study of intestinal goblet cell mucus from patients with $\mathrm{CF}$, demonstrated that calcium interacted with mucus anions resulting in significant dehydration and insolubility; conditions which might account for the formation of mucous "plugs."

The present study of the pancreas from patients who died with $\mathrm{CF}$ was undertaken to assess the degree of damage to this organ on the basis of morphometric and histometric observations. These were correlated with alterations in water content of the pancreas, the amount of extractable fat, and electrolyte concentrations.

\section{SPECIMENS AND METHODS}

Random sections, usually from the tail of the pancreas, weighing about $1 \mathrm{~g}$, were obtained postmortem from 35 individuals who died with $\mathrm{CF}$ and from 17 control subjects. Of the CF group, 16 were females and 19 were males. The ages at death ranged from 15 days to 23 years; 5 were under 5 months of age. Four infants had meconium ileus. The cause of death was listed as follows: severe pulmonary infection, 12; respiratory insufficiency, 6; cardiac arrest, 5 ; cor pulmonale, 5 ; meconium ileus, 3 ; pneumothorax, 3 ; hemorrhage, 1 .

Control specimens were from 5 females and 12 males aged 3 days to 13 years. Four specimens were from infants under 5 months of age. The patients in this group had the following diagnoses: leukemia, 4; tumors, 4; agammaglobulinemia, 2; auto accident, 1; asphyxia, I; tetralogy of Fallot, I; Wilson's disease, 1; thalassemia major, 1; congenital heart disease, 1; meningitis, 1.

A preliminary study of intrapancreatic chemical variability was undertaken to evaluate how closely a random section of pancreas may reflect the electrolyte composition of the whole pancreas. Two whole organs were dissected longitudinally and then cut into 20 separate sections each weighing between 0.6 and $1.2 \mathrm{~g}$. One pancreas was from a male patient with $\mathrm{CF}$ who died at $15 \% / 12$ years of age. This pancreas weighed $23.4 \mathrm{~g}$, or less than half of the expected weight. A second pancreas from a male child who died with a congenital heart defect at age $27 / 12$ and weighed $13.2 \mathrm{~g}$, within the expected weight range. This pancreas revealed no histologic or morphologic abnormalities.

The specimens were obtained within $2-8 \mathrm{hr}$ after death, and were immediately frozen. Before analyses, the original, or "wet" weight of the tissue was determined. The "dry" weight was obtained after overnight desiccation and served as the basis for the quantitative determination of electrolytes by atomic absorption spectroscopy (12).

\section{MORPHOMETRIC AND HISTOMETRIC STUDIES}

Percentages of various pancreatic tissue components, including fat, connective tissue, islets, acini, acinar ducts, and main ducts, were estimated in formalin-fixed, paraffin-embedded sections stained with hematoxylin and eosin prepared from 1-3 blocks of pancreas. The microscopic images were projected at 100 times magnification through an ocular lens containing an inscribed line to graph paper. The various types of tissue crossing or touching the line were counted. Ten such observations were made on each section, starting and subsequently moving the field at random, Total values for each component were then calculated as concentration (percentage). The percentages obtained from multiple blocks were averaged.

\section{RESULTS}

Weights of the organs and age at death are summarized in Table 1. Of the 16 pancreases, 11 were within the expected weight range and 2 each, in groups $I I$ and $I I I$, were below expected weight.

Without knowledge of the chemical composition, the pancreatic

Table 1. Weight of pancreas and age at death of 16 patients with cystic fibrosis ${ }^{1}$

\begin{tabular}{lccl}
\hline Sex & Age, yr & $\begin{array}{c}\text { Pancreas } \\
\text { wt, g }\end{array}$ & \multicolumn{1}{c}{ Comments } \\
\hline $\begin{array}{c}\text { Group I } \\
\text { M }\end{array}$ & $1 / 12$ & 4 & Meconium ileus \\
M & $2 / 12$ & 4 & Meconium ileus \\
F & $5 / 12$ & 6 & \\
Group II & & & \\
M & $5 / 12$ & 4 & Meconium ileus \\
F & $36 / 12$ & 15 & Meconium ileus \\
F & 5 & 39 & Diabetes, cirrosis \\
M & 20 & 19 & Pancreatic atrophy \\
Group III & & & \\
F & 4 & 14 & \\
F & 8 & 30 & Extensive calcification, \\
F & 12 & 30 & diabetes, and cirrhosis \\
& & & \\
M & $145 / 12$ & 58 & Cirrhosis \\
M & $158 / 12$ & 34 & \\
Group IV & & & \\
F & $75 / 12$ & 25 & Cirrhosis \\
F & 13 & 40 & \\
F & 15 & 62 & \\
M & $153 / 12$ & 45 & \\
\end{tabular}

${ }^{1}$ Expected pancreas mean weight (grams) at age: 1 month, 5.6; 2 months, $7.1 ; 5$ months, $11.0 ; 1-2$ years, $13.5 ; 2-4$ years, $19.0 ; 4-6$ years, $22.0 ; 6-12$ years, $29.0 ; 12-14$ years, $35.0 ; 14-16$ years, 68.0 ; Adult, $85-120$. 
sections from the above 16 specimens were grouped into four categories, in increasing order of pancreatic involvement on the basis of the morphometric data shown in Table 2. The values (mean and range) for each group are expressed as percentage of controls, taken as $100 \%$. Control levels for fatty infiltration are less than 1\%. Representative photomicrographs of one pancreatic section from each group are shown in Figures 1-4.

The results indicate that even in specimens from group I (taken from neonates who died under 5 months of age) considerable differences are seen in the concentration of acini, lobular and main ducts, and islets. Group $I I$ includes a young patient who had meconium ileus and a 20-year-old male who had not been diagnosed until 4 years before death. The concentrations of acini are markedly reduced, whereas main ducts increase to 18 times of control levels. There is minimal fatty infiltration (photomicrograph, Fig. 2)
Group III specimens are characterized by very large main ducts and more extensive fatty infiltration. The concentration of acini and lobular ducts are reduced to $6 \%$ and $75 \%$ of control levels, respectively (photomicrograph, Fig. 3)

All specimens from group IV show markedly decreased parenchymal and lobular duct elements. The fat concentration averaged $68 \%$ (53-92\%) (photomicrograph, Fig. 4)

\section{INTRAPANCREATIC CHEMICAL VARIABILITY}

The "mapping" of two whole pancreases each dissected into 20 individual sections shows a considerable range of concentration for each component (Table 3). The concentration of calcium, which ranged from 42 to $5,550 \mu \mathrm{g} / \mathrm{g}$ of dry tissue, was the most variable of all of the determinations in CF. In this pancreas four adjacent segments had concentrations of $144,5,550,4,930$, and $139 \mu \mathrm{g} \mathrm{Ca} / \mathrm{g}$

Table 2. Morphometric classification of pancreatic sections from 16 patients with cystic fibrosis

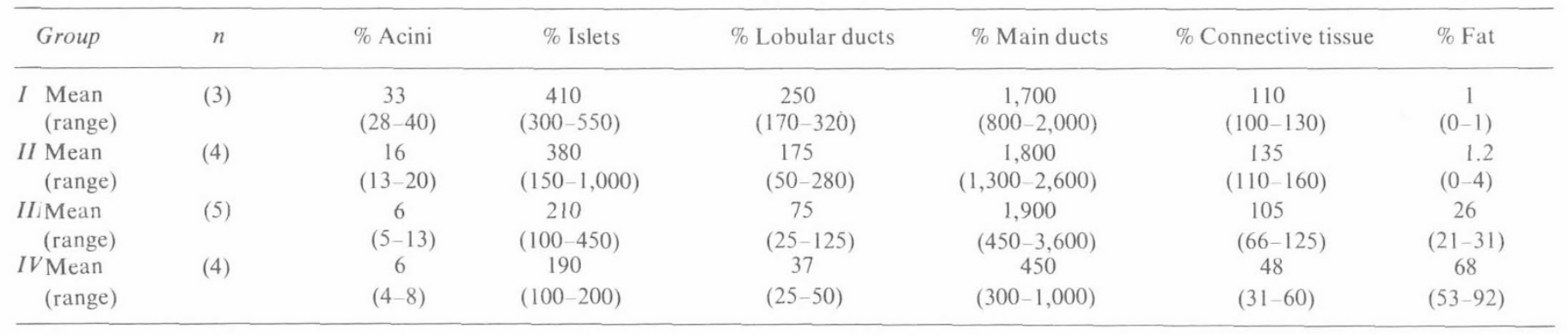

${ }^{1}$ Group mean values are expressed as percentage of control. Control equals 100 of all observations except percentage of fat, where control value is less than $1 \%$.

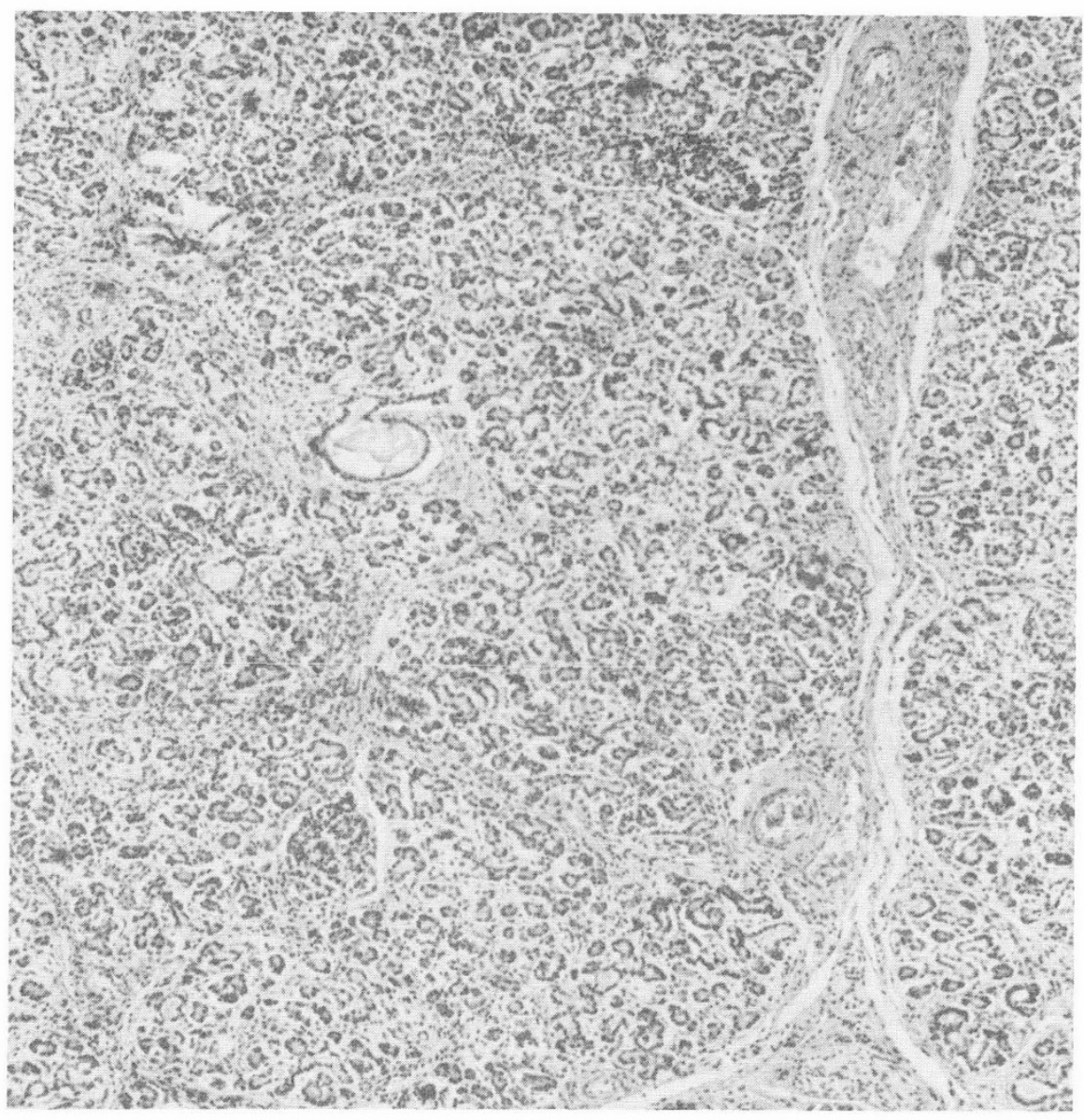

Fig. 1. Group I. Figures 1-4 are representative microscopic fields of cystic fibrosis pancreas. All photomicrographs are hematoxylin and eosin stained at magnification $\times 40$. There is a diffuse, fine interstitial fibrosis with mild intraductal secretion and intralobular ductular hyperplasia. 


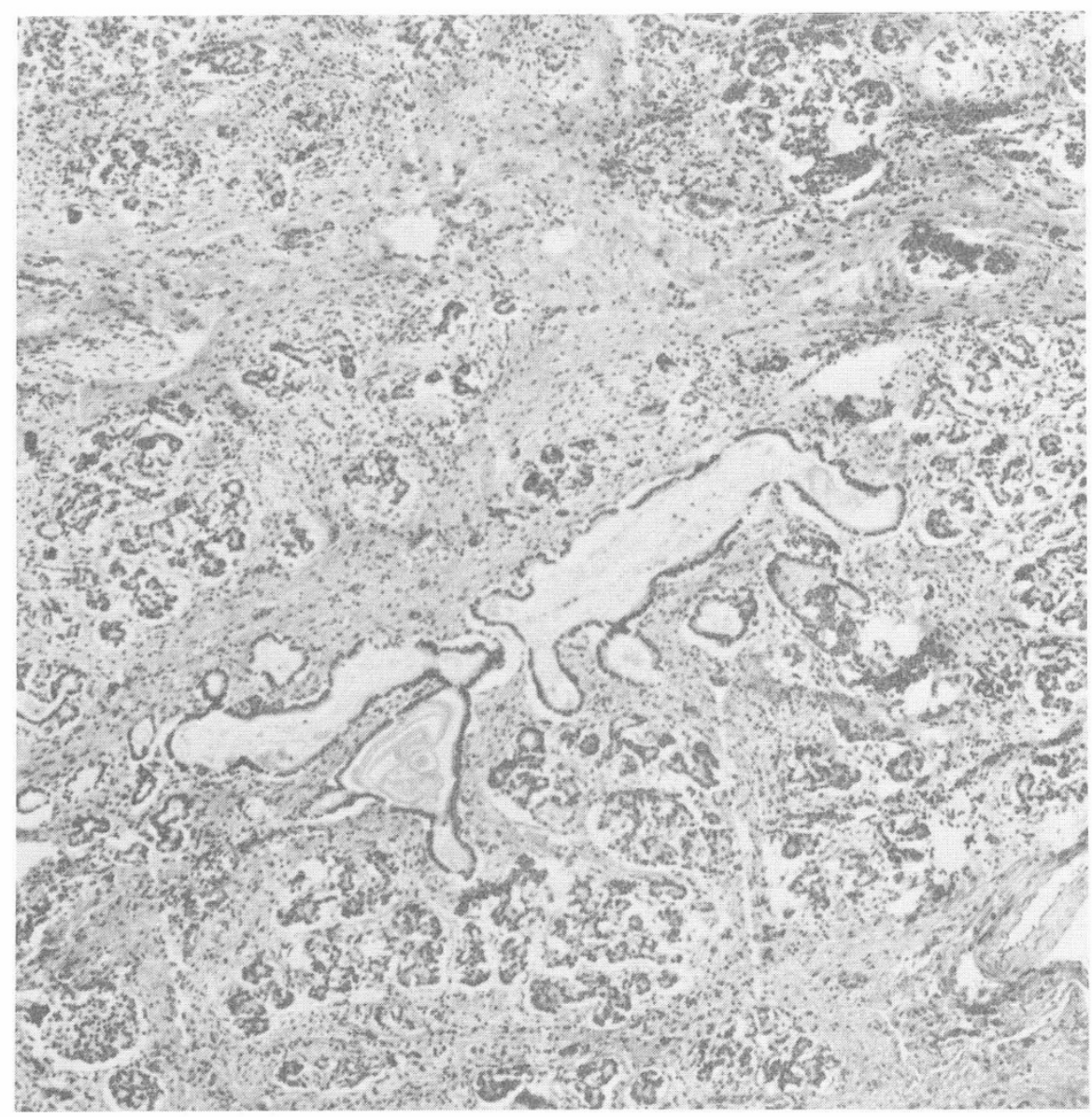

Fig. 2. Group II. Shows ductal secretory inspissation and acinar atrophy. Fibrosis is increaseci. See legend to Figure 1 for further details.

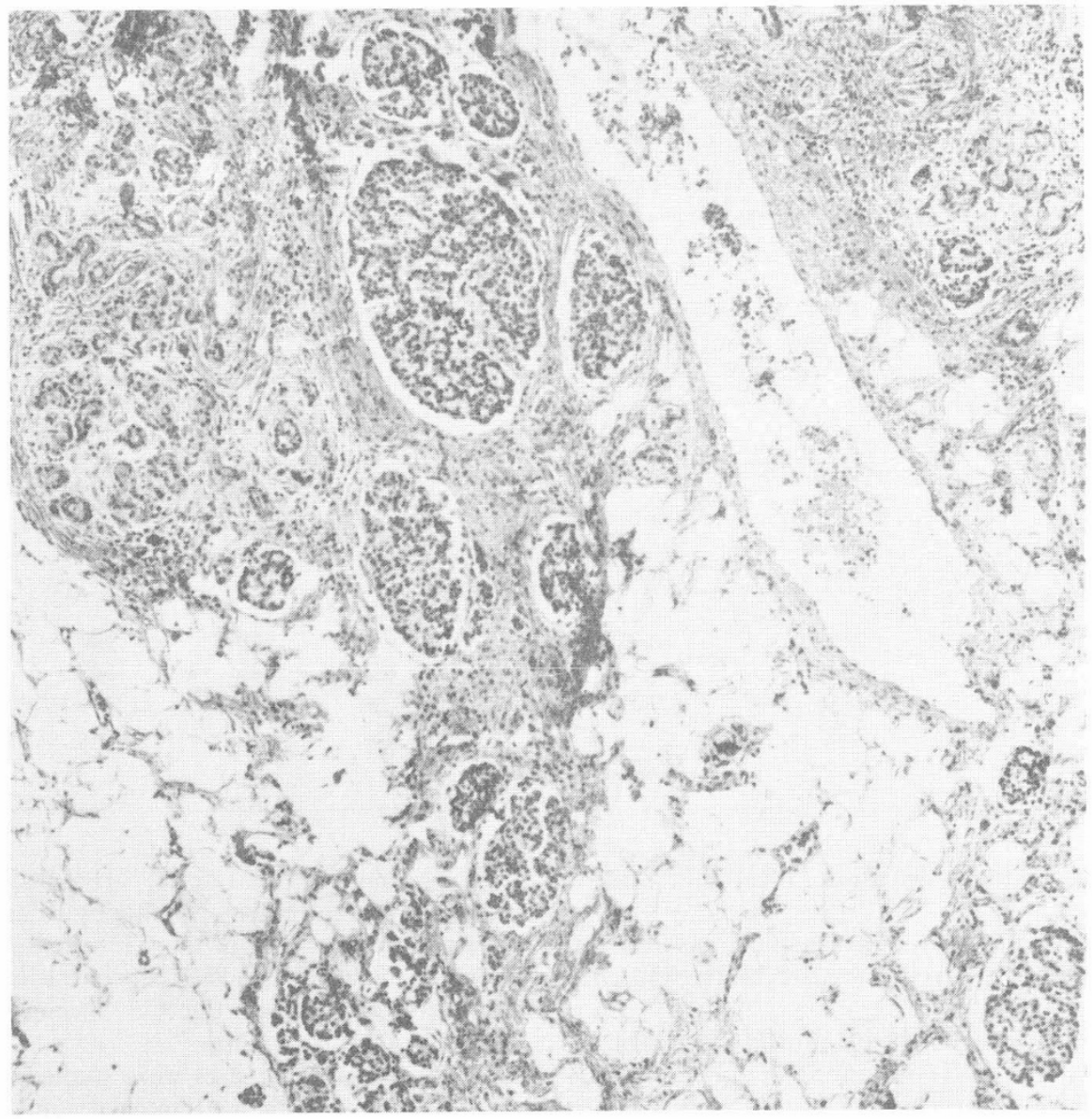

Fig. 3. Group III. Further reduction in exocrine parenchyma is seen with increasing perilobular adipose tissue. Acinar atrophy and fibrosis are increased. See legend to Figure 1 for further details. 


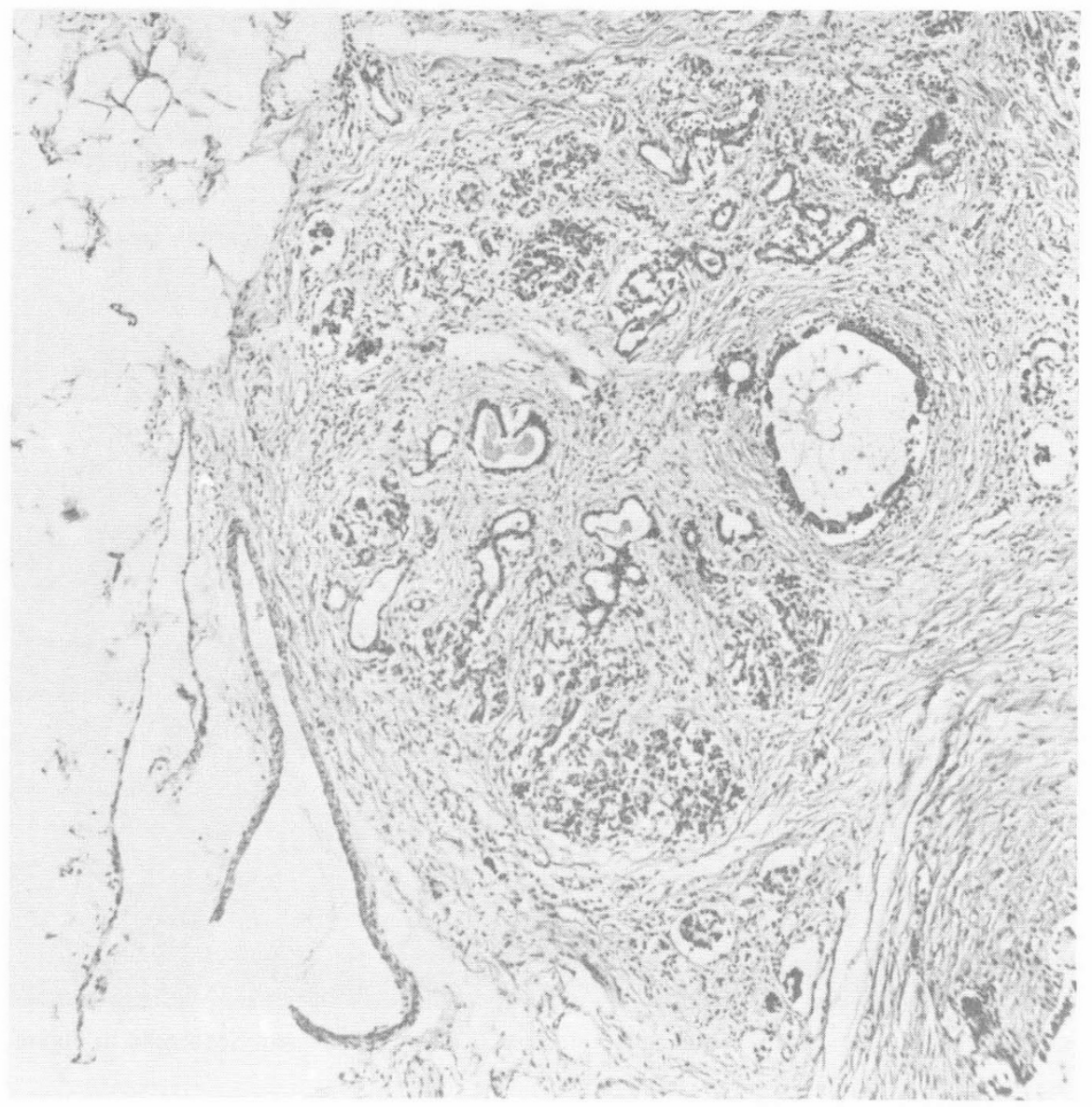

Fig. 4. Group IV. Only intralobular ductules remain, while acinar tissue is lacking. Adipose tissue further subdivides the residual glandular structure. Islets appear highly concentrated and some are very large. See legend to Figure 1 for further details.

Table 3. Intrapancreatic variability of electrolytes, fat, and volatile matter in two whole pancreases (based on 20 individual sections from each pancreas)

\begin{tabular}{|c|c|c|c|c|c|c|c|c|}
\hline & \multirow{2}{*}{$\begin{array}{l}\text { Dry weight } \\
\text { as \% of } \\
\text { wet weight }\end{array}$} & \multirow{2}{*}{$\begin{array}{l}\text { Fat as } \\
\% \text { of } \\
\text { wet weight }\end{array}$} & \multicolumn{4}{|c|}{ Concentration, $\mu \mathrm{g} / \mathrm{g}$ dry pancreas } & \multicolumn{2}{|c|}{$\begin{array}{c}\text { Concentration, } \mathrm{mEq} / \mathrm{kg} \\
\text { dry pancreas }\end{array}$} \\
\hline & & & $\mathrm{Zn}$ & $\mathrm{Cu}$ & $\mathrm{Ca}$ & $\mathrm{Mg}$ & $\mathrm{Na}$ & K \\
\hline \multicolumn{9}{|c|}{ Patient with cystic fibrosis } \\
\hline Arithmetic mean & 45 & 31 & 42 & 3.0 & 639 & 108 & 111 & 33 \\
\hline Median & 44 & 33 & 39 & 3.1 & 128 & 110 & 108 & 35 \\
\hline Range & $(30-69)$ & $(18-45)$ & $(22-70)$ & $(1.7-7.0)$ & $(42-5,550)$ & $(34-229)$ & $(43-166)$ & $(5-50)$ \\
\hline $\mathrm{SD}$ & 10 & $\begin{array}{c}8.9 \\
(12 \text { obs. })\end{array}$ & 13 & 1.4 & 1578 & 44 & 35 & 13 \\
\hline \multicolumn{9}{|c|}{ Patient with congenital heart defect } \\
\hline Arithmetic mean & 24 & 5.1 & 150 & 10 & 250 & 505 & 345 & 141 \\
\hline Median & 21 & 2.6 & 150 & 8.0 & 245 & 543 & 368 & 142 \\
\hline Range & $(19-36)$ & $(1-15)$ & $(93-219)$ & $(3-28)$ & $(158-300)$ & $(279-730)$ & $(169-553)$ & $(91-182)$ \\
\hline SD & 4.7 & $\begin{array}{l}5.2 \\
(9 \text { obs. })\end{array}$ & 39 & 7.5 & 48 & 135 & 116 & 31 \\
\hline
\end{tabular}

pancreas. The high concentrations of $\mathrm{Ca}$ were located in a ductal structure which was obstructed.

Selective sampling from the "tail" of the pancreas revealed much less chemical variability. For this reason only "tail-end" sections were used whenever possible.

A summary of all observations comparing mostly pancreatic tail sections of 35 patients with CF with those of 17 controls is presented in Table 4. Mean extractable fat was about 7 times higher in specimens from the CF group. The lowest fat level in a patient with $\mathrm{CF}$ was $2 \%$. This patient, who was followed by us since infancy, had normal pancreatic function through life and highly variable "sweat tests." He died at age 12 from severe pulmonary involvement. A moderate to severe water loss was observed in nearly all of the CF specimens with exception of the neonatal pancreases. The concentration of $\mathrm{Zn}$ and $\mathrm{Cu}$ were significantly lower in the CF specimens, averaging less than one-half of control values.

CF neonatal pancreases were studied separately in comparison with a group of four age-matched controls. The results, summarized in Table 5, show remarkable similarity between the two groups in the mean concentration of $\mathrm{Cu}, \mathrm{Mg}, \mathrm{Na}, \mathrm{K}$, and $\mathrm{Ca}$. Although the absolute $\mathrm{Zn}$ level in these CF neonatal specimens was 
not statistically significantly decreased, the ratio of $\mathrm{Zn}$ to ductules was less than one-fifth of controls and the ratio of $\mathrm{Zn}$ to ducts was about $3 \%$ of controls. None of the infant pancreases contained appreciable fat and only one CF specimen was dehydrated (55\% dry weight).

Alterations in electrolyte concentrations in the specimens classified by morphometric data (Table 6) show a striking correlation with the degree of pancreatic involvement. Severe dehydration occurred in all except one specimen of groups $I I, I I I$, and $I V$.

With the exception of $\mathrm{Ca}$ and $\mathrm{Mg}$, a significant diminution was observed in the concentration of all electrolytes. Zinc diminished from a mean of $193 \mu \mathrm{g} / \mathrm{g}$ dry pancreas in group I specimens to 106 , 42 , and $20 \mu \mathrm{g} / \mathrm{g}$ in specimens from groups $I I, I I I$, and $I V$, respectively.

In order to correct for the progressively larger fatty infiltration of the pancreas with the increasing severity of the pancreatic damage, fat was extracted with ethyl-ether and electrolytes were determined in the fat-free tissue. On this basis, specimens from patients of groups $I I I$ and $I V$ showed an increase in $\mathrm{Zn}$ levels to 62 and $57 \mu \mathrm{g} / \mathrm{g}$ from previous values of 42 and $20 \mu \mathrm{g} / \mathrm{g}$, respectively. However, even the corrected values were considerably below the control levels. Changes of similar magnitude were observed in other electrolytes. Calcium, the most variable of the pancreatic electrolytes, was greatly influenced by the presence or absence of inspissated mucus in the section analyzed; the unusually elevated $\mathrm{Ca}$ concentrations were associated with cystically dilated ducts, whereas lower values were found in sites adjacent to the cysts. These extremes in the distribution of $\mathrm{Ca}$ were most evident in group $I I$ and $I I I$ specimens (Table 6). The specimens with the highest calcium deposits were also recognized by histologic methods. In some patients the deposition of calcium in the pancreas could be detected by radiography. It is noteworthy that in three of four specimens of group $I V$ subjects, Ca levels were only 22,42 , and $59 \mu \mathrm{g} / \mathrm{g}$. In these sections there were few ducts and virtually no cysts.

Magnesium concentrations in the pancreatic sections varied in an erratic manner. Specimens of group IV patients had concentrations of $\mathrm{Mg}$ of $22,32,622$, and $728 \mu \mathrm{g} / \mathrm{g}$. Other group values were more homogeneous, particularly the specimens of group $I$ and $I I$.

Concentrations of sodium and potassium diminished markedly with increasing severity of the pancreatic disease, approaching levels of $10 \%$ or $15 \%$ of group I specimens and those of control values.

\section{DISCUSSION}

The unknown basic defect in cystic fibrosis causes widespread alterations in the mucus-secreting glands of the entire body (1).

Table 4. Electrolytes, fat, and volatile matter in random sections of pancreas from 35 patients with cystic fibrosis (CF) and 17 control subjects

\begin{tabular}{|c|c|c|c|c|c|c|c|c|}
\hline & \multirow{2}{*}{$\begin{array}{c}\text { Fat as } \\
\% \text { of } \\
\text { wet weight }\end{array}$} & \multirow{2}{*}{$\begin{array}{l}\text { Dry weight } \\
\text { as \% of } \\
\text { wet weight }\end{array}$} & \multicolumn{4}{|c|}{$\begin{array}{l}\text { Concentration, } \mu \mathrm{g} / \mathrm{g} \\
\text { dry pancreas }\end{array}$} & \multicolumn{2}{|c|}{$\begin{array}{c}\text { Concentration, } \mathrm{mEq} / \mathrm{kg} \\
\text { dry pancreas }\end{array}$} \\
\hline & & & $\mathrm{Zn}$ & $\mathrm{Cu}$ & $\mathrm{Ca}$ & $\mathrm{Mg}$ & $\mathrm{Na}$ & K \\
\hline \multicolumn{9}{|c|}{35 patients with $\mathrm{CF}$} \\
\hline Mean & 28 & 46 & 77 & 5.0 & 454 & 248 & 204 & 89 \\
\hline Range & $(2-57)$ & $(14-86)$ & $(9-248)$ & $(0.5-22)$ & $(27-5,550)$ & $(22-728)$ & $(22-655)$ & $(11-262)$ \\
\hline \multicolumn{9}{|c|}{17 controls } \\
\hline Mean & 4.1 & 26 & 193 & $13^{1}$ & 286 & 596 & 336 & 202 \\
\hline Range & $(0.1-21)^{2}$ & $(17-35)$ & $(99-496)$ & $(4-33)$ & $(124-580)$ & $(330-790)$ & $(186-714)$ & $(104-272)$ \\
\hline $\mathrm{SD}$ & $\begin{array}{c}7 \\
\text { (8 obs.) }\end{array}$ & 6 & 94 & 12 & 117 & 162 & 158 & 51 \\
\hline$P$ & $<0.001$ & $<0.001$ & $<0.001$ & $<0.001$ & $<0.001$ & $<0.01$ & $<0.001$ & $<0.001$ \\
\hline
\end{tabular}

${ }^{1}$ Patient who died with Wilson's disease is not included (the concentration of $\mathrm{Cu}$ in this pancreas was $49 \mu \mathrm{g} / \mathrm{g}$ ).

${ }^{2}$ Patient who died with agammaglobulinemia had a fatty pancreas $(20.2 \%$ extractable fat $)$.

Table 5. Electrolytes and volatile matter in section of pancreas from five neonates with cystic fibrosis $(C F)$ and four control subjects (age at death: under 5 months)

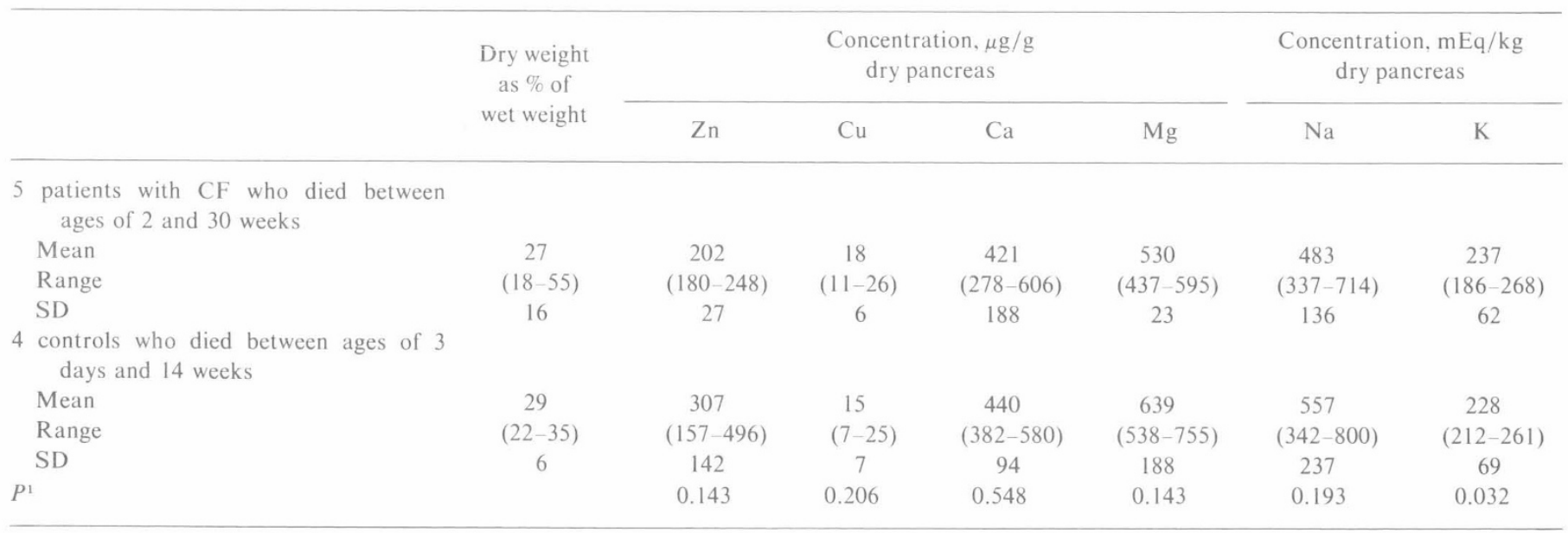

${ }^{1}$ By Mann-Whitney "U-test." 
Table 6. Electrolytes and volatile matter in sections of pancreas from patients with cystic fibrosis grouped according to severity of pancreatic involvement by morphometric data

\begin{tabular}{|c|c|c|c|c|c|c|c|}
\hline \multirow{2}{*}{ Group } & \multirow{2}{*}{$\begin{array}{l}\text { Dry weight } \\
\text { as \% of } \\
\text { wet weight }\end{array}$} & \multicolumn{4}{|c|}{$\begin{array}{l}\text { Concentration, } \mu \mathrm{g} / \mathrm{g} \\
\text { dry pancreas }\end{array}$} & \multicolumn{2}{|c|}{$\begin{array}{c}\text { Concentration, } \mathrm{mEq} / \mathrm{kg} \\
\text { dry pancreas }\end{array}$} \\
\hline & & $\mathrm{Zn}$ & $\mathrm{Cu}$ & $\mathrm{Ca}$ & $\mathrm{Mg}$ & $\mathrm{Na}$ & K \\
\hline \multicolumn{8}{|l|}{$I(n=3)$} \\
\hline Mean & 20 & 193 & 13.6 & 360 & 493 & 404 & 244 \\
\hline Range & $(18-22)$ & $(180-203)$ & $(11-15)$ & $(278-496)$ & $(437-530)$ & $(342-436)$ & $(214-261)$ \\
\hline $\mathrm{SD}$ & 2 & 12 & 2.3 & 119 & 49 & 54 & 26 \\
\hline \multicolumn{8}{|l|}{$I I(n=4)$} \\
\hline Mean & 48 & 106 & 8.5 & 506 & 438 & 371 & 156 \\
\hline Range & $(22-79)$ & $(37-184)$ & $(2.3-22)$ & $(98-1,300)$ & $(340-595)$ & $(138-755)$ & $(96-226)$ \\
\hline $\mathrm{SD}$ & 25 & 61 & 9.1 & 546 & 110 & 218 & 54 \\
\hline \multicolumn{8}{|l|}{$I I I(n=5)$} \\
\hline Mean & 51 & 42 & 2.4 & 955 & 126 & 133 & 52 \\
\hline Range & $(35-75)$ & $(25-61)$ & $(0.6-4.8)$ & $(34-3,270)$ & $(42-192)$ & $(45-211)$ & $(18-87)$ \\
\hline SD & 21 & 15 & 1.7 & 1548 & 69 & 72 & 32 \\
\hline \multicolumn{8}{|l|}{$I V(n=4)$} \\
\hline Mean & 69 & 20 & 1.8 & 139 & 351 & 57 & 18 \\
\hline Range & $(59-83)$ & $(9-29)$ & $(0.9-2.7)$ & $(27-447)$ & $(22-728)$ & $(22-104)$ & $(11-26)$ \\
\hline SD & 11 & 8 & 0.8 & 205 & 596 & 35 & 8 \\
\hline
\end{tabular}

The striking secondary changes in the pancreas are but one of the manifestations possible resulting from obstruction by inspissated secretions in the pancreatic acini and ducts.

The morphometric data in group $I$ and, especially, group II appear to confirm the diagnostic concept of fibrosis. The rich connective tissue content of the infant pancreas normally becomes quite inconspicuous by late childhood. Fibrosis is then evident in group $I I I$ in contrast to group $I V$, were relatively inconspicuous total concentrations of connective tissue are evident. At different stages of the pancreatic involvement there is active fibroplasia, dense heavy scar, or, finally, less conspicuous fibrosis. This suggests a considerable early, rapid, and later, slow erosion of connective tissue through the disease. The end-stage of pancreatic destruction is characterized by dehydration, liposclerosis, and calcification of intraductal concretions, similar to the sequence of events previously described by Blanc (2).

Of the electrolytes determined in this study, zinc and calcium are the most interesting from a functional point of view: Ionized calcium is one of the activators of trypsinogen, chymotrypsinogen, and lipase (4). In about $80 \%$ of patients with CF these enzymes show little or no activity (17).

Hematoxylinophilia is a well known morphologic indicator of mineral and calcium phosphates as in bone. Hematoxylinophilic ductal content was seen only in the two pancreases with the highest calcium concentration. Lack of this reaction in other segments of pancreas rich in calcium may indicate the presence of other than highly acidic phosphate bonding. For example, calcium oxalates are not hematoxylinophilic; it is more likely that this calcium is absorbed on to (neutral) protein or glycoproteins. Moreover, correlation with the morphometric data strongly indicates that calcium in pancreatic juice may be largely of duct epithelial origin, just as bicarbonates are thought to be. The excessive binding of calcium by intraductal secretions may be responsible for the formation of calcium soaps and ultimately, viscid insoluble obstructions. The depletion of $\mathrm{Ca}$ and $\mathrm{Ca}^{+}+$from tissues surrounding the inspissated material may alter membrane potentials and cause widespread changes in the physiochemical properties of the cell membrane. Rasmussen (15) suggested that the transport of water $\mathrm{Na}^{+}$and $\mathrm{K}^{+}$is governed by the degree and rate of dissociation of $\mathrm{Ca}$ to $\mathrm{Ca}^{++}$. The significant changes in $\mathrm{Ca}^{++}$binding observed in this study could, therefore, initiate the dehydration of the pancreas and induce the consequent parenchymal atrophy, fibrosis, and finally, fatty replacement.

Zinc is a constituent of a number of metalloenzymes including carbonic anhydrase $(0.3 \% \mathrm{Zn})$ and pancreatic carboxypeptidase $\mathrm{A}$ (1 gram-atom $\mathrm{Zn} /$ molecule) $(19,20)$.

Carboxypeptidase catalyzes the hydrolysis of carboxyterminal peptide bonds in proteins and peptides and also hydrolyzes esters. Carbonic anhydrase reversibly catalyzes the hydrolysis of carbon dioxide to form carbonic acid and bicarbonate (11). Although only a relatively small amount of $\mathrm{Zn}$ is required to activate these enzymes, a severe $\mathrm{Zn}$ deficiency (10) or a ductal obstruction may cause partial deactivation or immobilization of the available ionized $\mathrm{Zn}$. Impaired activation of these two essential pancreatic enzymes could result in dehydration, reduced bicarbonate production, changes in $\mathrm{pH}$, and reduced cleavage of proteins, conditions which have been observed in most pancreatic secretions from patients with CF. In particular, a consistent observation has been significantly reduced bicarbonate concentrations in this disease regardless of the state of nutrition of the patient or the presence of some of the proteolytic enzymes (9).

At birth and for several months later neonatal pancreases usually contain an excess of $\mathrm{Zn}$, averaging about $50 \%$ higher (per unit dry weight) than observed later in life. Increased $\mathrm{Zn}$ stores are also found in the neonatal CF specimens; however, the depletion of pancreatic $\mathrm{Zn}$ in the $\mathrm{CF}$ specimens appears to be rapid and severe. It is possible that $\mathrm{Zn}$ depletion in $\mathrm{CF}$ begins in utero, although the present data fail to confirm this with statistical certainty. This suggestion is supported by a previous study of $\mathrm{Zn}$ in meconium (13). Specimens of meconium collected within $10 \mathrm{hr}$ of birth from 65 apparently healthy neonates contained a mean concentration of $230 \mu \mathrm{g} \mathrm{Zn/g}$ dry meconium. Meconium from 8 infants with $\mathrm{CF}$ contained a mean $\mathrm{Zn}$ concentration of $157 \mu \mathrm{g} / \mathrm{g}$. In four patients with meconium ileus the analysis was done on material removed surgically from the obstructed gut. This meconium contained, on

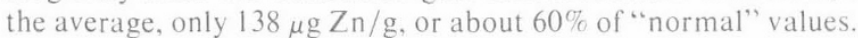

\section{SUMMARY}

Morphometric, histometric, and biochemical data are presented for 35 pancreases obtained from subjects who died with cystic fibrosis and 17 control subjects. The biochemical changes are quantitatively related to the severity of pancreatic involvement. At different stages of the disease there is active fibroplasia, liposclerosis, calcification, and considerable dehydration. Ductal structures are obstructed with viscous, calcium-rich inspissated material, whereas sections adjacent to obstructions are depleted of calcium. The degeneration of the pancreas appears to progress through life. 


\section{REFERENCES AND NOTES}

1. Allen, R. A., and Baggenstoss, A. H.: The pathogenesis of fibrocystic disease of the pancreas. Amer. J. Pathol., 31: 337 (1955).

2. Blanc, W. A.: Pathology of the pancreas and gastrointestinal tract. "GAP" Conference Reports, June 1972, National Cystic Fibrosis Research Foundation, Atlanta, Ga.

3. Bloomfield, J., Dascalu, J., VanLennep, E. W., and Brown, J.: Hypersecretion of zymogen granules in the pathogenesis of cystic fibrosis. Gut, 14: 558 (1973).

4. Busch, H.: Biochemical aspects of pancreatitis. Yale J. Biol. Med., 29: 596 (1957).

5. Chernick, W. S., and Barbero, G. J.: Studies on human tracheobronchial and submaxillary secretions in normal and pathophysiological conditions. Ann. N. Y. Acad. Sci., 106: 698 (1963).

6. di Sant'Agnese, P. A., and Talamo, R. C.: Pathogenesis and pathophysiology of cystic fibrosis of the pancreas. N. Engl. J. Med., 277: 1287 (1967).

7. Donnison, A. B., Shwachman, H., and Gross, R. E.: A review of 164 children with meconium ileus. Pediatrics, 37: 833 (1966).

8. Forstner, J. F., Jabbal, I., and Forstner, F. F.: Interaction of calcium with intestinal goblet cells. Clin. Res., 21: 1033 (1973).

9. Hadorn, B., Johansen, P. G., and Anderson, C. M.: Pancreozymin secretin tests of pancreatic function in cystic fibrosis and the significance of the results for the pathogenesis of the disease. Can. Med. Ass. J., 98: 377 (1968).

10. Hsu, J. M.: Pancreatic carboxypeptidases: Activities in zinc-deficient rats Science, 153: 882 (1966)

11. Kleiner, I. S., and Orten, J. M.: Biochemistry, p. 268 (C. V. Mosby, St. Louis, 1962).

12. Kopito, L.: Atomic Absorption Spectroscopy in Clinical Chemistry, Vol. II
(Fisher Scientific Co., Pittsburth, 1970).

13. Kopito, L., and Shwachman, H.: Mineral composition of meconium. J. Pediat., 68: 313 (1966)

14. Kopito, L, E., Kosasky, H. J., and Shwachman, H.: Water and electrolytes in cervical mucus from patients with cystic fibrosis. Fertil. Steril., 24: 512 (1973).

15. Rasmussen, H.: Cell communication, calcium ion, and cyclic adenosine monophosphate. Science, 107: 404 (1970).

16. Rule, A. H., Kopito, L. E., and Shwachman, H.: Chemical analysis of ejaculates from patients with cystic fibrosis. Fertil. Steril., 21: 515 (1970).

17. Shwachman, H., Dooley, R. R., Guilmette, F., Patterson, P. R., Weil, C., and Leubner, H.: Cystic fibrosis of the pancreas with varying degrees of pancreatic insufficiency. J. Dis. Child., 92: 347 (1956).

18. Shwachman, H., and Grand, R.: Cystic fibrosis. In: M. Slesinger and J. Fordtran: Gastrointestinal Diseases; Pathophysiology, Diagnosis and Management. (Saunders, Philadelphis, 1973).

19. Ting Kai Li: The functional role of zinc in metalloenzymes. In: A. S. Prasad: Zinc Metabolism, p. 48 (Charles C. Thomas, Springfield, Ill., 1966).

20. Vallee, B. L. Zinc and metalloenzymes, In: M. L. Anson, K. Bailey, and J. T. Edsall: Advances in Protein Chemistry, Vol. 10, p. 318 (Academic Press, New York, 1955).

21. The present address of Dr. L. E. Kopito is: Department of Nutrition, Massachusetts Institute of Technology, Cambridge, Mass.

22. The present address of Dr. J. Edlow is: Department of Pathology, Mt. Sinai Hospital, New York, N. Y.

23. Requests for reprints should be addressed to: H. Shwachman. The Children's Hospital, Medical Center, Boston, Mass. 02115 (USA).

24. Accepted for publication March 3, 1976
Calcitonin parathyroid hormone calcium phosphorus, inorganic magnesium plasma newborn

\title{
Calcium Metabolism in Newborn Animals: The Interrelationship of Calcium, Magnesium, and Inorganic Phosphorus in Newborn Rats, Foals, Lambs, and Calves
}

\author{
JEAN-MICHEL GAREL ${ }^{(48)}$ AND JEAN-PIERRE BARLET \\ Laboratoire de Physiologie du Developpement, Université Pierre et Marie Curie, Paris, and Physiopathologie de la \\ Nutrition, I.N.R.A. Theix, Beaumont, France
}

\section{Extract}

The plasma concentrations of calcium, inorganic phosphorus, and magnesium were studied during the early postnatal period in a rodent (rats), in ruminants (lambs and calves), and in foals. Decreases in plasma calcium after birth were observed only in newborn rats and foals. In rats the postnatal fall in plasma calcium level was already evident $1 \mathrm{hr}$ after cesarean section $(9.20 \mathrm{mg} / 100$ $\mathrm{ml}$ ) as opposed to $11.90 \mathrm{mg} / 100 \mathrm{ml}$ in utero) and reached a nadir within $6 \mathrm{hr}(-4.05 \mathrm{mg} / 100 \mathrm{ml})$. Newborn foals showed a small decrease in plasma calcium $(-0.73 \mathrm{mg} / 100 \mathrm{ml}) 48 \mathrm{hr}$ after birth. In the four species, plasma inorganic phosphorus increased in the days after birth; plasma magnesium levels were only slightly affected over the first week of life. In ruminants and in foals, the high plasma calcitonin levels were not always related to plasma calcium, nor with plasma inorganic phosphorus over the first week of life. Newborn calves showed at birth detectable levels of plasma parathyroid hormone, similar to those found in their mothers, with individual values ranging from $0.80-3.50 \mathrm{ng} / \mathrm{ml}$. These re- sults are discussed in light of the well known early neonatal hypocalcemia occurring in normal human newborns.

\section{Speculation}

The parathyroid status at birth is species dependent. In some species, it has been suggested that in utero, high plasma calcium levels inhibit the parathyroid function before birth, but other unknown factors may be involved in this suppression. The maturity of the renal cortex adenyl cyclase activity in the early postnatal period is also species dependent and the degree of renal immaturity is not sufficient to explain the postnatal increase in plasma inorganic phosphorus.

Hypocalcemia is well known to occur in human neonates but is strangely unreported in animals. It has been postulated that hyperphosphatemia per se, transient hypoparathyroidism, and/or endorgan unresponsiveness might explain the early postnatal de- 